\title{
FEATURES OF STOMATOLOGIC STATUS, TELOMERE LENGTHS AND PHENOTYPE OF IMMUNOCOMPETENT CELLS OF PERIPHERAL BLOOD IN CHILDREN - RESIDENTS OF UKRAINIAN TERRITORIES, CONTAMINATED WITH RADIONUCLIDES
}

\author{
Svitlana Liubarets \\ Department of Pediatric and Preventative Dentistry \\ Bogomolets National Medical University \\ 13 Shevchenko blvd., Kyiv, Ukraine, 01601 \\ slub@ukr.net \\ Irina Iliyenko \\ Laboratory of Immunology and Cytology \\ State Institution "National Research Center for Radiation Medicine of the National Academy of \\ Medical Sciences of Ukraine" \\ 53 Melnikova str., Kyiv, Ukraine, 04050 \\ ilyenko@ukr.net \\ Tetiana Liubarets \\ Department of Radiation Oncohematology and Blood Stem Cells Transplatation \\ Institute of Clinical Radiology of the State Institution "National Research Center for Radiation \\ Medicine of the National Academy of Medical Sciences of Ukraine" \\ 53 Melnikova str., Kyiv, Ukraine, 04050 \\ tliubarets@yahoo.com \\ Olena Lyaskivska \\ Laboratory of Immunology and Cytology \\ State Institution "National Research Center for Radiation Medicine of \\ the National Academy of Medical Sciences of Ukraine" \\ 53 Melnikova str., Kyiv, Ukraine, 04050 \\ Nataliia Bidenko \\ Department of Pediatric and Preventative Dentistry \\ Bogomolets National Medical University \\ 13 Shevchenko blvd., Kyiv, Ukraine, 01601 \\ natali.bidenko.kiev@gmail.com \\ Oleksandr Savychuk \\ Department of Pediatric and Preventative Dentistry \\ Bogomolets National Medical University \\ 13 Shevchenko blvd., Kyiv, Ukraine, 01601 \\ oleksandr.savychuk@gmail.com \\ Dymytriy Bazyka \\ Department of Clinical Immunology \\ Institute of Clinical Radiology of the State Institution \\ "National Academy of Medical Sciences of Ukraine" \\ 53 Melnikova str., Kyiv, Ukraine, 04050 \\ bazyka@yahoo.com
}

Abstract

Objective of research. To analyze features of stomatological status indices, relative length of telomeres and phenotype of immunocompetent cells of peripheral blood in children with chronological enamel hypoplasia - residents of Ukrainian territories, contaminated with radionuclides after the Chornobyl NPP accident. 
Materials and methods. The object of research is chronological enamel hypoplasia (CEH) of permanent teeth, and lymphocytes of peripheral blood (PB). The subject of research is the state of oral cavity hygiene, caries intensity, gingivitis severity degree, relative telomere length (RTL), and phenotype of immunocompetent cells (ICC) of PB. Methods of the research: stomatological, immunological (flow cytofluorometry), molecular genetic (fluorescence in situ hybridization-flow cytometry flow-FISH), statistical.

Results. Two types of the analysis of the stomatologic status, RTL and phenotype of PB ICC were carried out: the first is the comparison of indices of the combined group of children with anamnesis complicated by radiation (group No. 1 with CEH + group No. 2 without CEH) comparing with the control group No. 3; the second is the analysis of indeces of the group No. 1 comparing with the same markers in children of the groups No. 2 and No. 3. The first stage of the analysis shows the significant worsening of oral hygien indices, high DMFT in children with permanent dentition, higher degree of gums inflamation and moresignificant RTL shortening in children of the combined group (No. $1+$ No. 2) comparing with the control. Changes of the same character, but more expressed observed during the another analysis concerning the children with anamnesis complicated by radiation and CEH comparing with the control. Reliable changes in the content of PB ICC subpopulations in the examined children of all groups were not identified.

\section{Conclusions:}

1. In children with $\mathrm{CEH}$, complicated by ionizing radiation (IR) influence in low doses diapason the highest degree of stomatological status disorders comparing with the examined reference and control groups was determined: unsatisfactory and poor oral cavity hygiene according to OHI-S $(1.76 \pm 0.41, \mathrm{p}<0.0001$ and $\mathrm{p}<0.0001$, respectively) and Silness-Loe index $(1.73 \pm 0.45, \mathrm{p}<0.0001$ and $\mathrm{p}<0.0001$, respectively); very high intensity of dental caries $((\mathrm{DMFT}=7.0 \pm 2.29, \mathrm{p}=0.003$ and $\mathrm{p}<0.0001 ; \mathrm{DMFS}=8.74 \pm 2.58, \mathrm{p}=0.0004$ and $\mathrm{p}<0.0001$, respectively); mean degree of gingivitis severity (PMA 47.55 $\pm 14.27 \%, \mathrm{p}<0.0001$ and $\mathrm{p}<0.0001$, respectively).

2. At CEH, which occurs due to the complex of negative factors during first years of life, including IR in residents of territories with effective doses more than $1.0 \mathrm{mSv} / \mathrm{year}$, reliable shortening of relative telomeres length of PB lymphocytes comparing with the control group $(15.17 \pm 3.20, \mathrm{p}=0.0002)$ was found. Reliable differences in the content of peripheral blood immunocompetent cells when compared the examined groups were not identified.

3. Results of indices of the groups No. 1-3 comparison are agreed with the data, obtained in result of dispersive analysis that allowed to separate the most informative indices concerning stomatological examination of children: OHI-S ( $\mathrm{F}=34.92 ; \mathrm{p}<0.001)$; Silness-Loe index $(\mathrm{F}=27.01 ; \mathrm{p}<0.001)$; dft+DMFT $(\mathrm{F}=82.23 ; \mathrm{p}<0.001) ; \mathrm{dfs}+\mathrm{DMFS}(\mathrm{F}=49.41 ; \mathrm{p}<0.001) ; \mathrm{DMFT}(\mathrm{F}=13.94 ; \mathrm{p}<0.001)$; DMFS $(F=19.41 ; p<0.001)$; PMA $(F=41.25 ; p<0.001)$; RTL $(F=7.53 ; p=0.001)$.

Keywords: children, chronological teeth enamel hypoplasia, ionizing radiation, immunocompetent cells of peripheral blood, relative telomere length.

\section{Introduction}

Pediatric health is an integral index of the entire societal wellbeing which depends on the influence of social and ecologic factors [1]. Deterioration of somatic health in children occurs under the unfavorable environmental impacts through a functional modification of protective systems including the immune one, predisposing therefore to a higher risk of somatic disease [2, 3]. Enamel hypoplasia (ICD-10 code K00.40) is among the most prevalent tooth formation disorders (ICD-10 code K00.4). This abnormality of permanent teeth in children is a result of metabolic disorders due to the influence of a range of endogenous and exogenous factors e. g. somatic and infectious diseases, unbalanced nutrition, environmental pollution, etc. during the in utero period or the first years of life $[4,5]$.

Ionizing radiation is a hazardous environmental factor significantly affecting children's health. This issue had become of especial concern upon the Chornobyl Nuclear Power Plant (ChNPP) accident. The literature data point to the significant 1.25-1.5-fold increase of general morbidity in children with compromised radiation anamnesis at the background of poor indices of immune status $[6,7]$.

Unfavorable environmental impacts, in particular IR, even in a low doses, are among the factors modifying the function of numerous body systems including an immune one [8]. Abnormal cellular function is a consequence of the free radical formation, DNA breakage induction, cellular "aging" to which the "counting" function of telomere sequences and apoptosis are supposed to be linked. According to results of experimental research, the telomere shortening including that in 
germ cells is linked to elongation of a cell cycle arrest, intensified apoptosis, and increased frequency of chromosome aberrations and probability of malignant transformation [9]. The role of telomere shortening is extensively studied in pathogenesis of numerous somatic diseases. The same issue in neurological and mental diseases (autism) is of especial concern in some research projects [10] supposed being a consequence of chronic stress in children [11].

It is known that telomere length is directly linked to the number of cellular cycles and becomes shorter along with cellular "aging". There are extensive molecular-genetic studies conducted in this field last years. In some of them, the associations of telomere length (TL) in adult patients were estimated, namely the TL from peripheral blood WBC in case of periodontal tissue lesions [12], TL of dental DNA depending on an age [12], depending on the age, gender, and type of teeth (molar ones etc.) [13], length of terminal restrictive fragment as the DNA TL analogue from dental pulp for age assessment [14]. The TL, telomerase and reverse transcriptase activity, surface antigens of papillary dental stem cells, pulp, follicles and mesenchymal stem cells from bone marrow [15] were assayed in comparative aspect in a favor of restorative dentistry. No data however are available in literature about the TL abnormalities in children with tooth disorders and enamel hypoplasia in particular.

In children born or living in unfavorable ecological conditions, congenital malformations, as well as clinical manifestations of general and local dysplasia, in particular $\mathrm{CEH}$, were found $[16,17]$. Thus, CEH progressing growth is considered to be connected with effects of the Chornobyl accident [17]. Nevertheless, single studies devoted to estimation of the general immune condition in children with $\mathrm{CEH}$ and complicated radiation anamnesis are merely displayed in literature.

\section{Objective of research}

To analyze features of the stomatological status indices, relative telomeres length and phenotype of immunocompetent cells of peripheral blood in children with chronological enamel hypoplasia - residents of Ukrainian territories, contaminated with radionuclides after the Chornobyl NPP accident.

\section{Materials and methods}

54 children aged $8-18$ years (mean age was $14.00 \pm 2.55$ years), hospitalized at Radiation Pediatric Endocrinology department of the State Institution "National Research Center for Radiation Medicine of the National Academy of Medical Sciences of Ukraine" (SI NRCRM NAMS of Ukraine) were examined. All the children assigned to the $3^{\text {rd }}$ health group [18]. According to the "Helsinki declaration" (2000), the children and their parents were informed about the aim and methods of the research, its potential benefits and risks, probable discomfort at diagnostic and other manipulations prior to the study. The children's anamnestic data were obtained from the medical cards. The examination included the medical history, the children interview, external examination and the oral cavity examination.

Determination of enamel hypoplasia forms in examined children was carried out according to Yu. A. Fedorov and co-authors classification (1997) [19]. For the differential diagnostics of $\mathrm{CEH}$ and caries, enamel vital staining and transillumination methods were used [18]. Hygienic condition of the oral cavity was determined by Green-Vermillion index (Oral Hygienic Index Simplex-OHI-S) (1964), that estimates dental plaque area, and Silness Loe index (1976), that assesses the thickness of the tooth plaque near the cervical area [18]. To characterize caries process, dental caries intensity indicators were used (WHO, 1980). Caries intensity was estimated using indices for mixed dentition dft+DMFT (decayed, filled (primary teeth) + decayed, missing, filled (permanent teeth)), for permanent dentition DMFT (decayed, missing, filled), for surfaces - dfs+DMFS (decayed, filled surfaces (primary teeth) and DMFS (decayed, missing, filled surfaces (permanent teeth)) for mixed and permanent dentition, respectively) [18].

To estimate the gingivitis severity degree, the Papillary Marginal Alveolar Index - PMA (Parma, 1960; Masser, 1967) was used [18].

ICC PB phenotype was studied by flow cytofluometry method in direct immunofluorescence test using monoclonal antibody (MCAB) panels (Becton Dickinson (BD), USA). PB bio- 
logical samples were taken from the cubital vein in test tubes containing heparin in the concentration $20 \mathrm{un} / \mathrm{ml}$.

Biomaterial preparation for the immunofluorescence test analysis was as follows: $10 \mu 1$ of MCAB and $50 \mu \mathrm{l}$ of the biomaterial were put at the bottom of the plastic tube; the sample was mixed using vortex mixer S 411 (TGL, Germany) during 3 seconds and then incubated during 20-30 min in darkness, at the temperature $21-27^{\circ} \mathrm{C}$; for the lysis of erythroid elements Lysing Solution was used (BD, USA) - $1 \mathrm{ml} / \mathrm{sample}$. The immunocytofluorimetric analysis of the PB cells was realized using five scatter parameters - FSC (forward side scatter) - direct scatter index (cells size determination) and orthogonal SSC $\left(90^{\circ}\right)$ (side scatter) - side scatter index (optical density characteristic for cellular cytoplasm, types of cellular inclusions and cell granularity); three detection channels of specific fluorescent signal at different wave lengths: FL1, FL2, FL3.

According to the scatter markers, the differentiation of leukocyte subpopulations was realized - lymphocytes, monocytes and granulocytes. Monoclonal antibody (MCAB) panel included: CD3/19, CD4/8, CD3/HLA-DR, CD3/16/56, marked by two fluorochromes: Fluorescein isothiocyanate (FITC) and Phycoerythrin (PE). Fluorescent microspheres «Calibrite» (BD, USA), labeled by fluorescent marks FITC, PE and MCAB to mice immunoglobulins, were used as a control. The analysis was carried out by laser flow cytofluometry FACSCalibur (BD, USA) with fluoriscence excitation registration at wave length of $488 \mathrm{~nm}$.

Determination of RTL of PB lymphocytes was carried out using Telomer PNA Kit/FITC (Dako Cytometration, Denmark) set and flow-FISH method (flow cytometry-fluorescence in situ hybridization). The set is recommended for determination of telomeres in nuclear hematopoietic cells using samples of nucleic acid peptide (PNA), bound with fluorescein.

Immunological studies were carried out at the laboratory of immunocytology of the Clinical Radiology Institute of the SI "NRCRM NAMS of Ukraine".

The distribution of examined persons by groups was the following: the group No. $1-24$ children with $\mathrm{CEH}$ - residents of III and IV zones territories, contaminated with $\mathrm{Cs}^{137}$ after the Chornobyl NPP accident with pollution density of 1-15 Ci/sq km (effective doses are more than $1.0 \mathrm{mSv} /$ year); the group No. 2 - 15 residents of III and IV zones of radioactive contamination without $\mathrm{CEH}$, the group No. 3 - 15 persons of child age without $\mathrm{CEH}$ and with uncomplicated radiation anamnesis. Two types of analysis were realized: the first analysis was devoted to comparison of indices in children from the combined group with anamnesis complicated by irradiation (group No. $1+$ group No. 2) comparing with the control group No. 3; the second study was devoted to the analysis of the indices of the group No. 1 comparing with the same indices in children from the No. 2 and No. 3 groups, as well as among groups No. 2 and No. 3.

The statistical data processing was carried out using MS Excel 10 and Statictica 10 software.

\section{Results of research}

The first analysis testified that the hygienic status of the main combined group of children (group No. $1+$ group No. 2) with anamnesis complicated by irradiation was satisfactory, OHI-S index was $1.42 \pm 0.60(\mathrm{t}=4.54, \mathrm{p}<0.0001)$ (Table 1), in children of the control group (No. 3) it was good $(0.62 \pm 0.53)$. Silness-Loe index in patients of the main group corresponded to the bad hygiene of the oral cavity $(1.42 \pm 0.58, \mathrm{t}=3.88, \mathrm{p}=0.0003)$, in the group No. 3 - to the good hygiene $(0.67 \pm 0.57)$.

The markers of caries intensity in children of the main group with mixed dentition were $6.38 \pm 1.6(t=7.13, p<0.0001)$ concerning $\mathrm{dft}+\mathrm{DMFT}$, and $7.75 \pm 2.05(\mathrm{t}=6.32, \mathrm{p}<0.0001)$ concerning dfs + DMFS, i. e. they sufficiently differed from the indices of the control group (Table 1). The reliably higher dental caries intensity was diagnosed in examined patients of the combined group with the permanent dentition: DMFT was 5.94 $\pm 2.63(\mathrm{t}=3.76, \mathrm{p}=0.0006)$, and DMFS was $7.26 \pm 3.15$ $(\mathrm{t}=4.04 ; \mathrm{p}=0.0002)$.

In children of the control group, medium degree of gingivitis severity was diagnosed PMA $36.66 \pm 19.22 \%$, that reliably $(\mathrm{t}=4.47, \mathrm{p}<0.0001)$ differed from the index in children of the group No. 3 (13.03 $\pm 10.96 \%$ ), characterized by slight degree of the mentioned disorder.

The telomere length in children with anamnesis complicated by irradiation was essentially lower comparing to the control group $-15.9 \pm 3.43$ and $18.99 \pm 1.88$, respectively $(t=-3.29 ; \mathrm{p}=0.002)$ 
(Table 2). Reliable differences in the content of main PB lymphocytes subpopulations in both groups of examined children were not identified (Table 2).

Table 1

Hygienic indices, dental caries intensity and gingivitis severity degree in children with anamnesis complicated by irradiation (group No. $1+$ No. 2) comparing with the control group

\begin{tabular}{|c|c|c|c|c|c|c|c|}
\hline \multirow{2}{*}{$\begin{array}{l}\text { Examined } \\
\text { groups, (n) }\end{array}$} & \multicolumn{2}{|c|}{ Hygienic indices } & \multicolumn{2}{|c|}{$\begin{array}{l}\text { Caries intensity } \\
\text { (mixed dentition) }\end{array}$} & \multicolumn{2}{|c|}{$\begin{array}{c}\text { Caries intensity } \\
\text { (permanent dentition) }\end{array}$} & \multirow{2}{*}{$\begin{array}{l}\text { Gingivitis sever- } \\
\text { ity degree, \% } \\
\text { PMA, } \\
\mathrm{M} \pm \mathrm{SD} \text { (n) }\end{array}$} \\
\hline & $\begin{array}{l}\text { OHI-S, } \\
\mathbf{M} \pm \text { SD (n) }\end{array}$ & $\begin{array}{l}\text { Silness-Loe Index, } \\
\quad \mathbf{M} \pm \mathbf{S D} \text { (n) }\end{array}$ & $\begin{array}{c}\text { dft+DMFT, } \\
M \pm \text { SD (n) }\end{array}$ & $\begin{array}{c}\text { dfs+DMFS, } \\
\text { M } \pm \text { SD (n) }\end{array}$ & $\begin{array}{l}\text { DMFT, } \\
\text { M } \pm \text { SD (n) }\end{array}$ & $\begin{array}{l}\text { DMFS, } \\
\text { M } \pm \text { SD (n) }\end{array}$ & \\
\hline $\begin{array}{c}\text { No. } 1+ \\
+ \text { No. } 2(\mathrm{n}=39)\end{array}$ & $1.42 \pm 0.60^{1}(39)$ & $1.42 \pm 0.58^{3}(36)$ & $6.38 \pm 1.6^{1}(8)$ & $7.75 \pm 2.05^{1}(8)$ & $5.94 \pm 2.63^{4}(31)$ & $7.26 \pm 3.15^{2}(31)$ & $36.66 \pm 19.2$ \\
\hline No. $3(n=15)$ & $0.62 \pm 0.53(15)$ & $0.67 \pm 0.57(12)$ & $0.8 \pm 0.84(5)$ & $1.2 \pm 1.3(5)$ & $2.4 \pm 2.41(10)$ & $2.8 \pm 2.61(10)$ & $13.03 \pm 10.96(15)$ \\
\hline
\end{tabular}

Note: ${ }^{1}-p<0.0001 ;{ }^{2}-p=0.0002 ;{ }^{3}-p=0.0003 ;{ }^{4}-p=0.0006$ comparing with the control group

Table 2

Phenotypes of PB lymphocytes and reliable telomere length (RTL) in children with anamnesis complicated by irradiation (group No. $1+$ No. 2) comparing with the control group

\begin{tabular}{|c|c|c|}
\hline Index & $\begin{array}{c}\text { Combined main group (No. } 1+\text { No. } 2) \\
\qquad M \pm S D(n=39)\end{array}$ & $\begin{array}{c}\text { Group No. } 3 \text { (control) } \\
\quad \mathbf{M} \pm \operatorname{SD}(\mathrm{n}=15)\end{array}$ \\
\hline RTL & $15.9 \pm 3.43^{*}$ & $18,99 \pm 1,88$ \\
\hline $\mathrm{CD}^{+}$(T-lymphocytes), $\%$ & $60,16 \pm 10.93$ & $59.49 \pm 9.15$ \\
\hline $\mathrm{CD} 9^{+}$(B-lymphocytes), \% & $9.15 \pm 4.37$ & $8.37 \pm 3.29$ \\
\hline $\mathrm{CD}^{+}$(T-helpers), $\%$ & $31.09 \pm 8.26$ & $30.24 \pm 7.58$ \\
\hline $\mathrm{CD}^{+}$(T-suppressors/cytoxic T-lymphocytes), $\%$ & $27.09 \pm 5.9$ & $26.84 \pm 7.78$ \\
\hline $\mathrm{CD}^{+} / \mathrm{CD}^{+}$immunoregulatory index & $1.17 \pm 0.31$ & $1.26 \pm 0.67$ \\
\hline $\mathrm{CD}^{+}{ }^{+} \mathrm{DR}^{+}$(activated T-cells), $\%$ & $2.61 \pm 1.46$ & $2.54 \pm 1.53$ \\
\hline CD3-DR ${ }^{+}$(activated B-cells), $\%$ & $11.37 \pm 3.65$ & $12.63 \pm 4.05$ \\
\hline $\begin{array}{c}\mathrm{CD}^{+} 16^{+} 56^{+} \\
\text {(NK lymphocytes/cytotoxic), \% }\end{array}$ & $8.43 \pm 2.12$ & $4.88 \pm 3.1$ \\
\hline CD3-16 $56^{+}$(NK lymphocytes), $\%$ & $13.74 \pm 7.04$ & $15.02 \pm 10.17$ \\
\hline
\end{tabular}

Note: ${ }^{*}-p=0.002$ comparing with the control group

The second type of the analysis has shown that in the examined children of the group No. 1 state of oral cavity hygiene was estimated as unsatisfactory, according to OHI-S (1.76 \pm 0.41$)$ index, and in the group No. 2 it was estimated as satisfactory $(0.88 \pm 0.43)$. OHI-S of the group No. 1 sufficiently differed from the control group index and reference group $(\mathrm{t}=7.56, \mathrm{p}<0.0001$ and $\mathrm{t}=6.47$, $\mathrm{p}<0.0001$, respectively) (Table 3). Silness-Loe indices in children of the main group corresponded to bad oral cavity hygiene $(1.73 \pm 0.45)$, in patients of the groups No. 2 and No. 3 - to good $(0.87 \pm 0.34$ and $0.67 \pm 0.57$, respectively), and the differences weresignificant $(\mathrm{t}=6.04, \mathrm{p}<0.0001$ and $\mathrm{t}=6.06$, $\mathrm{p}<0.0001$, respectively).

Caries intensity (dft+DMFT) in children of the groups No. 1, No. 2 and No. 3 with mixed dentition was $7.4 \pm 0.89,4.67 \pm 0.58$ and $0.8 \pm 0.84$ respectively, and reliably differed from the control 
and reference groups $(\mathrm{t}=12.05, \mathrm{p}<0.0001$ and $\mathrm{t}=4.66, \mathrm{p}=0.003$, respectively) (Table 3$)$. $\mathrm{dfs}+\mathrm{DMFS}$ in children of the group No. 1 with mixed dentition was sufficiently higher than the markers of the groups No. 3 and No. 2 ( $\mathrm{t}=9.75, \mathrm{p}<0.0001$ and $\mathrm{t}=3.8, \mathrm{p}=0.009$, respectively).

In residents of the controlled territories with CEH (group No. 1), rather high intensity of permanent teeth caries was diagnosed - 7.0 \pm 2.29 (Table 3). In the structure of DMFT index of this group, the "D" component prevailed. Medium severity of caries was typical for the children group No. 2. DMFS index in the examined patients of No. 1 and No. 2 groups was $8.74 \pm 2.58$ and $4.92 \pm 2.54$, respectively. DMFT of the group No. 1 reliably differed $(t=5.06, p<0.0001)$ from the index of the control group, the same significant changes were found concerning DMFT index relative to the reference group $(\mathrm{t}=3.25, \mathrm{p}=0.003)$. DMFS in children of the group No. 1 was reliably higher comparing to the groups No. 3 and No. $2(t=5.86, p<0.0001$ and $t=4.04, p=0.0004$, respectively).

Gingivitis severity degree was considered to be medium in children of the group No. 1 $(47.55 \pm 14.27 \%)$ and mild $(19.23 \pm 11.8 \%)$ in examined patients of the group No. 2 (Table 3). The reliable increase of the index of children with anamnesis complicated by irradiation with CEH in relation to examined patients from the control and reference groups $(\mathrm{t}=8.0, \mathrm{p}<0.0001$ and $\mathrm{t}=6.43$, $\mathrm{p}<0.0001$, respectively) was identified.

Table 3

Hygienic indices, caries intensity, gingivitis severity degree in the examined children

\begin{tabular}{lccccccc}
\hline & \multicolumn{2}{c}{ Hygienic indices } & \multicolumn{2}{c}{$\begin{array}{c}\text { Caries intensity } \\
\text { (mixed dentition) }\end{array}$} & \multicolumn{2}{c}{$\begin{array}{c}\text { Caries intensity } \\
\text { (permanent dentition) }\end{array}$} & $\begin{array}{c}\text { Gingivitis sever- } \\
\text { ity degree, \% }\end{array}$ \\
$\begin{array}{c}\text { Examined } \\
\text { groups, (n) }\end{array}$ & $\begin{array}{c}\text { OHI-S, } \\
\text { M } \pm \text { SD (n) }\end{array}$ & $\begin{array}{c}\text { Silness-Loe } \\
\text { Index, } \\
\mathbf{M} \pm \text { SD (n) }\end{array}$ & $\begin{array}{c}\text { dft+DMFT, } \\
\mathbf{M} \pm \text { SD (n) }\end{array}$ & $\begin{array}{c}\text { dfs+DMFS, } \\
\mathbf{M} \pm \text { SD (n) }\end{array}$ & $\begin{array}{c}\text { DMFT, } \\
\text { M } \pm \text { SD (n) }\end{array}$ & $\begin{array}{c}\text { DMFS, } \\
\text { M } \pm \text { SD (n) }\end{array}$ & $\begin{array}{c}\text { PMA, } \\
\text { M } \pm \text { SD (n) }\end{array}$ \\
\hline No. 1 (n=24) & $1.76 \pm 0.41^{* 3}(24)$ & $1.73 \pm 0.45^{* 3}(23)$ & $7.4 \pm 0.89^{* 1}(5)$ & $9.0 \pm 1.22^{* 2}(5)$ & $7.0 \pm 2.29^{* 1}(19)$ & $8.74 \pm 2.58^{* 4}(19)$ & $47.55 \pm 14.27^{* 3}(24)$ \\
No. 2 (n=15) & $0.88 \pm 0.43(15)$ & $0.87 \pm 0.34(13)$ & $4.67 \pm 0.58(3)$ & $5.67 \pm 1.15(3)$ & $4.25 \pm 2.30(12)$ & $4.92 \pm 2.54(12)$ & $19.23 \pm 11.8(15)$ \\
No. 3 (n=15) & $0.62 \pm 0.53(15)$ & $0.67 \pm 0.57(12)$ & $0.8 \pm 0.84(5)$ & $1.2 \pm 1.3(5)$ & $2.4 \pm 2.41(10)$ & $2.8 \pm 2.61(10)$ & $13.03 \pm 10.96(15)$
\end{tabular}

Note: ${ }^{*}-p<0.0001$ comparing with the control group ${ }^{1}-p=0.003 ;{ }^{2}-p=0.009 ;{ }^{3}-p<0.0001 ;{ }^{4}-p=0.0004$ relative to the reference group

The relative telomere length in residents of the controlled territories with $\mathrm{CEH}$ was $15.17 \pm 3.20$ and reliably differed from the control group $(\mathrm{t}=-4.18, \mathrm{p}=0.0002)$. In children of the reference group and control group, RTL was $17.07 \pm 3.57$ and 18.99 \pm 1.88 , respectively (Table 4). Reliable differences in the content of main PB lymphocytes subpopulations in the children of examined groups were not identified (Table 4).

Table 4

Phenotype of PB lymphocytes and relative telomere length (RTL) in the examined children

\begin{tabular}{|c|c|c|c|}
\hline Index & $\begin{array}{l}\text { Group No. } 1 \text { (main) } \\
\quad M \pm S D(n=24)\end{array}$ & $\begin{array}{c}\text { Group No. } 2 \text { (reference) } \\
\qquad M \pm S D(n=15)\end{array}$ & $\begin{array}{c}\text { Group No. } 3 \text { (control) } \\
\quad \mathbf{M} \pm \operatorname{SD}(\mathbf{n}=15)\end{array}$ \\
\hline RTL & $15.17 \pm 3.20^{*}$ & $17.07 \pm 3.57$ & $18.99 \pm 1.88$ \\
\hline $\mathrm{CD}^{+}$(T-lymphocytes), \% & $60.10 \pm 11.77$ & $60.26 \pm 9.82$ & $59.49 \pm 9.15$ \\
\hline CD19+ (B-lymphocytes), \% & $9.17 \pm 3.95$ & $9.12 \pm 5.12$ & $8.37 \pm 3.29$ \\
\hline $\mathrm{CD}^{+}$(T-helpers), $\%$ & $30.03 \pm 7.6$ & $32.77 \pm 9.23$ & $30.24 \pm 7.58$ \\
\hline $\mathrm{CD}^{+}$(T-suppressors/cytoxic T-lymphocytes), \% & $27.02 \pm 6.55$ & $27.22 \pm 4.89$ & $26.84 \pm 7.79$ \\
\hline $\mathrm{CD}^{+} / \mathrm{CD}^{+}$immunoregulatory index & $1.12 \pm 0.23$ & $1.23 \pm 0.40$ & $1.26 \pm 0.67$ \\
\hline $\mathrm{CD}^{+} \mathrm{DR}^{+}$(activated T-cells), $\%$ & $2.62 \pm 1.62$ & $2.59 \pm 1.2$ & $2.54 \pm 1.53$ \\
\hline CD3-DR ${ }^{+}$(activated B-cells), \% & $11.533 \pm 3.52$ & $11.10 \pm 3.96$ & $12.63 \pm 4.05$ \\
\hline $\mathrm{CD}^{+} 16^{+} 56^{+}$(NK lymphocytes/cytotoxic), $\%$ & $5.98 \pm 3.52$ & $12.35 \pm 34.3$ & $4.88 \pm 3.1$ \\
\hline CD3-16 $56^{+}$(NK lymphocytes), $\%$ & $14.14 \pm 6.65$ & $13.10 \pm 7.8$ & $15.02 \pm 10.17$ \\
\hline
\end{tabular}

Note: $*-p=0.0002$ comparing with the control group 
The displayed results of comparison of indices in children from the groups No. 1-3 are consistent with the data, obtained in result of disperse analysis that allowed to highlight the following most informative indices: OHI-S $(\mathrm{F}=34.92 ; \mathrm{p}<0.001)$; Silness-Loe index $(\mathrm{F}=27.01 ; \mathrm{p}<0.001)$; $\mathrm{dft}+\mathrm{DMFT}(\mathrm{F}=82.23 ; \mathrm{p}<0.001)$; dfs + DMFS $(\mathrm{F}=49.41 ; \mathrm{p}<0.001)$; DMFT $(\mathrm{F}=13.94 ; \mathrm{p}<0.001)$; DMFS $(\mathrm{F}=19.41 ; \mathrm{p}<0.001)$; PMA $(\mathrm{F}=41.25 ; \mathrm{p}<0.001) ; \operatorname{RTL}(\mathrm{F}=7.53 ; \mathrm{p}=0.001)$.

\section{Discussion}

It is well-known, that decrease of the oral cavity hygiene simultaneously with CEH in children is due to the difficultness in brushing of deformed teeth [20]. Poor oral cavity hygiene was found in schoolchildren having dental hard tissue anomalies, especially enamel hypoplasia, with uncomplicated radiation anamnesis [21]. In the examined children from the group No. 1, affected by low doses of IR, unsatisfactory oral cavity hygiene was determined that corresponds to the literary data concerning state of oral cavity hygiene in children with $\mathrm{CEH}[22,23]$.

It is known, that higher hygienic indices pointing to poor oral cavity hygiene are substantiated by a number of factors, including morphological changes of the enamel structure [4]. At hypoplasia, the enamel disorder may occur both in visible changes area, and throughout the whole enamel area adjacent to the damage area. On the margin of intact enamel andthe hypoplastic area, the quantity of different forms and sizes of pores increases that promotes different microflora fixation there resulting to complications, especially caries. In the examined children, affected by IR, the spotted CEH form was diagnosed. Spots were superficial, scabrous at probing, with changed color pointing to amelogenesis imperfecta during enamel formation period, which causes more expressed microflora adhesion and sufficiently worsens oral cavity hygiene $[4,18]$. Besides, CEH appearance is caused by the complex of negative factors in child's organism during first years of life, including IR.

Contrary to our results, according to the data [17] at examination of children with $\mathrm{CEH}$, living in Ivano-Frankivsk region in areas contaminated with products of chemical industry and radionuclides after the ChNPP accident (IV zone), OHI-S in all groups of examined children was satisfactory.

From our point of view, the presence of hypoplastic enamel and poor level of the oral cavity hygiene may be factors causing gingivitis. In children of the group No. 1, PMA index was $47.55 \pm 14.27 \%$ and it corresponded to medium gingivitis severity degree. In III-IV zones residents, contaminated by $\mathrm{Cs}^{137}$, without complications by $\mathrm{CEH}$ (group No. 2) PMA index corresponded to mild gingivitis severity degree. In literature, there are few information concerning the mentioned index in children with CEH. Thus, PMA index in children with CEH - residents of Ivano-Frankivsk region, affected by different factors (chemical and IR) was low [17], that doesn't correspond to our results.

In children of our group No. 1 - residents of III and IV zones with CEH, rather high teeth caries intensity (DMFT $=7 \pm 2.29$ ) was diagnosed, similar results were obtained [17] at examination of the children - residents of IV zone with radioactive contamination (Snyatinsky district of Ivano-Frankivsk region) with $\mathrm{CEH}$, but the degree of intensity of changes in that group was lower (nothing but high intensity of caries was found $-\mathrm{DMFT}=5.93 \pm 0.41$ ). In examined residents of III-IV zones, contaminated by $\mathrm{Cs}^{137}$, without CEH (group No. 2) DMFT index corresponded to medium caries intensity.

In examined children of the main group, first or second permanent molars were injured more often $(54.5 \%)$, separately or in combination with incisors or premolars injury. In the same children, it was established, that RTL decrease was essentially higher $(\mathrm{p}<0.0001)$ comparing with the control group (No. 3), that may be caused by the complex effect of negative factors including IR influence. Our results correspond to the data [14], obtained at the study of TL of dental DNA of different age groups of patients (15-85 years), and the highest TL was found in molars.

It known, that shortening of lymphocyte telomere length increases cell apoptosis, promotes disorders of immune system and organism health in general and can be a result of the effect of stress factors, IR, different diseases, unbalanced nutrition, etc. [5, 10, 11]. During examination of children aged 3-15 years [19], it was found, that the effect of stress factors in childhood affects 
telomere length (causes telomere ends shortening), connected with negative results for organism in future and may be a criterion for health indices prognosis.

At determination of relative telomere lengths, apoptosis degree and some features of PB lymphocytes radiation aging of clean-up workers of the ChNPP accident in 1986-1987 and persons, working in especially dangerous and harmful labor conditions (the "Shelter" object of ChNPP), after low doses irradiation, the dose-depending decrease of RTL sequences of PB lymphocytes was determined. Identified changes positively correlated with the increase of early apoptosis level, most pronounced in clean-up group [25]. In the late period after irradiation in wide doses interval, system disorders of main regulatory mechanisms of ICC functioning including FAS-mediated apoptosis, protein kinase system activation and cellular "aging", connected with disorders of expression of apoptosis regulatory genes, signal transduction genes and cellular proliferation, as well as genes that regulate telomere length, were diagnosed [26].

Nowadays, normative values of ICC content for healthy children of different age [27] are determined. In the examined children, the inessential decrease of $\mathrm{CD}^{+} \mathrm{T}$-lymphocytes in examined patients of the $1^{\text {st }}, 2^{\text {nd }}$ and $3^{\text {rd }}$ groups $(60.10 \pm 11.77,60.26 \pm 9.82,59.49 \pm 9.15 \%$, respectively), comparing with mean statistical value for 7-17 aged children (66-76\%), takes place [23]. It is known, the most functional role of $\mathrm{CD}^{+}$cells is in participation in the signal transmission from $\alpha$ - and $\beta$-chains that recognize antigen inside the cell, starting the process of its activation with the further proliferation [28].

$\mathrm{CD}^{+}$and $\mathrm{CD}^{+} \mathrm{T}$-lymphocytes subpopulations are immunoregulatory cells, and immune response depends on their ratio in the organism [28]. Some decrease of CD4 $4^{+}$-lymphocytes relative to normative values (33-41\%) was diagnosed in the examined patients from all studied groups. According to the literary data, decrease of $\mathrm{CD} 4^{+}$lymphocytes occurs at infectious, allergic and other diseases and may be used as a predictors of their course [29, 30]. The amount of CD8 ${ }^{+}$(T-suppressors/cytotoxic) T-lymphocytes in the examined children from groups No. 1-3 corresponded to the lower limit of standard values $(27.02 \pm 6.55,27.22 \pm 4.89,26.84 \pm 7.79 \%$, respectively). Immunoregulatory index in all groups did not differ from the norm (1-1.4), although the literary data show the change of this index in the children with the somatic pathology [31]. The absence of significant changes of main PB ICC subpopulations content at comparison in the examined groups probably will be reviewed in subsequent studies as a result of the increase of representative groups.

\section{Conclusions}

1. In children with CEH, complicated by IR influence in low doses diapason the highest degree of stomatological status disorders comparing with the examined reference and control groups was determined: unsatisfactory and poor oral cavity hygiene according to OHI-S (1.76 \pm 0.41 , $\mathrm{p}<0.0001$ and $\mathrm{p}<0.0001$, respectively) and Silness-Loe index $(1.73 \pm 0.45, \mathrm{p}<0.0001$ and $\mathrm{p}<0.0001$, respectively); very high intensity of dental caries (DMFT $=7.0 \pm 2.29, \mathrm{p}=0.003$ and $\mathrm{p}<0.0001$; $\mathrm{DMFS}=8.74 \pm 2.58, \mathrm{p}=0.0004$ and $\mathrm{p}<0.0001$, respectively); mean degree of gingivitis severity (PMA $47.55 \pm 14.27 \%, \mathrm{p}<0.0001$ and $\mathrm{p}<0.0001$, respectively).

2. At $\mathrm{CEH}$, which occurs due to the complex of negative factors during first years of life, including IR in residents of territories with effective doses more than $1.0 \mathrm{mSv} /$ year, reliable shortening of relative telomeres length of PB lymphocytes comparing with the control group (15.17 \pm 3.20 , $\mathrm{p}=0.0002$ ) was found. Reliable differences in the content of peripheral blood immunocompetent cells when compared the examined groups were not identified.

3. Results of indices of the groups No. 1-3 comparison are agreed with the data, obtained in result of dispersive analysis that allowed to separate the most informative indices concerning stomatological examination of children: OHI-S ( $\mathrm{F}=34.92 ; \mathrm{p}<0.001)$; Silness-Loe index $(\mathrm{F}=27.01$; $\mathrm{p}<0.001) ; \mathrm{dft}+\mathrm{DMFT} \quad(\mathrm{F}=82.23 ; \mathrm{p}<0.001) ; \mathrm{dfs}+\mathrm{DMFS}(\mathrm{F}=49.41 ; \mathrm{p}<0.001) ;$ DMFT $(\mathrm{F}=13.94$; $\mathrm{p}<0.001)$; DMFS $(\mathrm{F}=19.41 ; \mathrm{p}<0.001)$; PMA $(\mathrm{F}=41.25 ; \mathrm{p}<0.001)$; RTL $(\mathrm{F}=7.53 ; \mathrm{p}=0.001)$.

\section{Acknowledgements}

We express gratitude to head and staff of the laboratory of immunocytology of the Clinical Radiology Institute for the possibility to realize immunologic and molecular genetic studies; 
staff of the Radiation Pediatric Endocrinology Department of the State Institution "National Research Center for Radiation Medicine of the National Academy of Medical Sciences of Ukraine" (SI NRCRM NAMS of Ukraine) for the possibility to carry out clinical and stomatological examination in children.

\section{References}

[1] Moyiseyenko, R. O. (2009). Chastota ta struktura zakhvoryuvanosti ditey v Ukrayini ta shlyakhy yii znyzhennya. Sovremennaya pediatriya, 2 (24), 10-14.

[2] Bezvushko, E. V. (2013). Stomatolohichna zakhvoryuvanist' ditey, yaki prozhyvayut' na riznykh za ekolohichnym stanom terytoriyakh, ta obhruntuvannya dyferentsiyovanoyi profilaktyky urazhen' tverdykh tkanyn zubiv. Kyiv, 36.

[3] Luchynskyi, M. A. (2014). Stan stomatolohichnoho zdorovya ta adaptatsiyni mozhlyvosti orhanizmu ditey iz zuboshchelepnymy anomaliyamy $\mathrm{v}$ umovakh poyednanoyi diyi chynnykiv antropohennoho $\mathrm{i}$ pryrodn'oho henezu. Lviv, 36.

[4] Leus, P. A. (2008). Nekarioznye bolezni tverdyh tkanei zubov. Minsk: BGMU, 56.

[5] Matasar, I. T., Lutsenko, O. H., Petryshchenko, L. M., Matasar, V. I. (2014). Osoblyvosti kharchovoho statusu ta esentsial'ni nutriyentni defitsyty sered naselennya radioaktyvno zabrudnenykh terytoriy Ukrayiny. Dovkillya ta zdorovia, 1, 38-41.

[6] Kopylova, O. V., Stepanenko, O. A. (2015). Osoblyvosti funktsionuvannya hipotalamo-hipofizarno-tyreoyidnoyi systemy ditey, narodzhenykh vid osib, oprominenykh unaslidok avariyi na ChAES. Ukrayins'kyi radiolohichnyi zhurnal, 23 (3), 58-60.

[7] Stepanova, E. Y., Kondrashova, V. H., Vdovenko, V. Yu., Kolpakov, Y. E., Voloshko, V. Y., Leonovych, O. S. (2015). Dysfunktsiya endoteliyu ta stan sertsevo-sudynnoyi systemy u ditey, yaki narodylysya ta postiyno prozhyvayut' na radioaktyvno zabrudnenykh terytoriyakh. Mezhdunarodnyi zhurnal pedyatrii, akusherstva i hynekolohii, 7 (2), 34-43.

[8] Vozianov, O. F., Bebeshko, V. H., Bazyka, D. A. (Eds.) (2007). Medychni naslidky avariyi na Chornobyl's'kiy atomniy elektrostantsiyi. Kyiv: DIA, 800.

[9] Kalmbach, K. H., Fontes Antunes, D. M., Dracxler, R. C., Knier, T. W., Seth-Smith, M. L., Wang, F. et. al. (2013). Telomeres and human reproduction. Fertility and Sterility, 99 (1), 23-29. doi: 10.1016/ j.fertnstert.2012.11.039

[10] Drury, S. S. (2015). Unraveling the Meaning of Telomeres for Child Psychiatry. Journal of the American Academy of Child \& Adolescent Psychiatry, 54 (7), 539-540. doi: 10.1016/j.jaac.2015.04.009

[11] Costa, D. de S., Rosa, D. V. F., Barros, A. G. A., Romano-Silva, M. A., Malloy-Diniz, L. F., Mattos, P., de Miranda, D. M. (2015). Telomere length is highly inherited and associated with hyperactivity-impulsivity in children with attention deficit/hyperactivity disorder. Frontiers in Molecular Neuroscience, 8. doi: $10.3389 /$ fnmol.2015.00028

[12] Sanders, A. E., Divaris, K., Naorungroj, S., Heiss, G., Risques, R. A. (2014). Telomere length attrition and chronic periodontitis: an ARIC Study nested case-control study. Journal of Clinical Periodontology, 42 (1), 12-20. doi: 10.1111/jcpe.12337

[13] Marquez-Ruiz, A. B., Gonzalez-Herrera, L., Valenzuela, A. (2017). Usefulness of telomere length in DNA from human teeth for age estimation. International Journal of Legal Medicine. doi: 10.1007/ s00414-017-1595-5

[14] Takasaki, T., Tsuji, A., Ikeda, N., Ohishi, M. (2003). Age estimation in dental pulp DNA based on human telomere shortening. International Journal of Legal Medicine, 117 (4), 232-234. doi: 10.1007/ s00414-003-0376-5

[15] Jeon, B.-G., Kang, E.-J., Kumar, B. M., Maeng, G.-H., Ock, S.-A., Kwack, D.-O. et. al. (2011). Comparative Analysis of Telomere Length, Telomerase and Reverse Transcriptase Activity in Human Dental Stem Cells. Cell Transplantation, 20 (11-12), 1693-1705. doi: 10.3727/096368911x565001

[16] Wertelecki, W., Ievtushok, B., Zymak-Zakutnia, N., Kalynka, S., Korzhynskyy, Y., Lapchenko, S., Sosyniuk, Z. (2016). Vrodzheni vady rozvytku, Polissya, Chornobyl. Neonatolohiia, khirurhiia ta perynatal'na medytsyna, 6 (2 (20)), 5-15. 
[17] Labiy, Yu. A. (2016). Shlyakhy pidvyshchennya rezystentnosti emali zubiv u ditey, khvorykh na systemnu hipoplaziyu, shcho prozhyvayut' $\mathrm{v}$ rayonakh iz riznym antropohennym zabrudnennyam. Ivano-Frankivsk, 168.

[18] Homenko, L. A., Kisel'nikova, L. P. (2010). Terapevticheskaia stomatologiia detskogo vozrasta. Kyiv: Kniga plius, 804.

[19] Fedorov, Yu. A., Kibrocashvili, I. A. (2007). Nekotorye osobennosti rasprostranennosti i klinicheskogo proiavleniia nekarioznyh porazhenii zubov, razvivshihsia v period ih formirovaniia (do prorezyvaniia). Stomatologiia detskogo vozrasta i profilaktika, 1, 47-52.

[20] Kibrocashvili, I. A. (2007). Klinika, diagnostika i lechenie gipoplazii emali i shodnyh s nei zabolevanii zubov u detei i podrostkov. Saint Petersburg, 20.

[21] Popoola, B. O., Onyejaka, N., Folayan, M. O. (2016). Prevalence of developmental dental hard-tissue anomalies and association with caries and oral hygiene status of children in Southwestern, Nigeria. BMC Oral Health, 17 (1). doi: 10.1186/s12903-016-0236-6

[22] Volyak, L. M. (2013). Profilaktyka ta likuvannya systemnoyi hipoplaziyi emali postiynykh zubiv u ditey z endemichnym zobom. Odessa, 20.

[23] Kril, I. A., Rozhko, M. M. (2011). Poshyrenist systemnoyi hipoplaziyi emali u shkolyariv m. Ivano-Frankivska. Halytskyi likarskyi visnyk, 18 (2), 53-55.

[24] Coimbra, B. M., Carvalho, C. M., Moretti, P. N., Mello, M. F., Belangero, S. I. (2017). Stress-related telomere length in children: A systematic review. Journal of Psychiatric Research, 92, 47-54. Available at: https://www.researchgate.net/publication/316034727 doi: 10.1016/j.jpsychires.2017.03.023

[25] Ilenko, I. M., Lyaskivska, O. V., Bazyka, D. A. (2012). Dovzhyna telomernykh poslidovnostey ta apoptoz limfotsytiv peryferychnoyi krovi lyudyny u ranniy ta viddalenyi periody pislya oprominennya. Zhurnal NAMN Ukrayiny, 18 (1), 115-119.

[26] Ilenko, I. M. (2016). Henna rehulyatsiya apoptozu, proliferatsiyi ta starinnya imunokompetentnykh klityn lyudyny u rann'omu ta viddalenomu periodakh pislya oprominennya. Kyiv, 38.

[27] Tyazhka, O. V. (2016). Pediatriya. Kyiv, 1152. Available at: http://www.novaknyha.com.ua/item/ addToCart $/ 556$

[28] Fathimunisa, B. (2014). Immunology. Delhi: Prentice-Hall of India Pvt. Ltd, 614.

[29] Mandala, W. L., MacLennan, J. M., Gondwe, E. N., Ward, S. A., Molyneux, M. E., MacLennan, C. A. (2010). Lymphocyte subsets in healthy Malawians: Implications for immunologic assessment of HIV infection in Africa. Journal of Allergy and Clinical Immunology, 125 (1), 203-208. doi: 10.1016/ j.jaci.2009.10.010

[30] Marusyk, U. I., Storoshchuk, T. K. (2014). Pokaznyky klitynnoyi lanky imunnoyi systemy u shkolyariv, khvorykh na tyazhku formu bronkhialnoyi astmy. Halytskyi likarskyi visnyk, 21 (2), 54-56.

[31] Senatorova, H. S., Lupaltsova, O. S. (2012). Kliniko-laboratorni aspekty perebihu hostrykh bronkhitiv u ditei. Eksperymentalna i klinichna medytsyna, 2 (55), 113-116. Available at: http://repo.knmu. edu.ua/handle/123456789/1296 